УДК 338.48

\title{
ФОРМУВАННЯ КОНКУРЕНТНИХ ПЕРЕВАГ ПІДПРИЕМСТВ СФЕРИ ТУРИЗМУ
}

\section{FORMATION OF THE COMPETITIVE ADVANTAGES OF TOURISM ENTERPRISES}

\author{
Чергінець Валерія Максимівна \\ магістр з туризму, \\ Національний університет харчових технологій \\ ORCID: https://orcid.org/0000-0001-5771-6198 \\ Примак Тетяна Юхимівна \\ кандидат фрізико-математичних наук, доцент, \\ Національний університет харчових технологій \\ ORCID: https://orcid.org/0000-0003-0682-8717 \\ Cherhinets Valeriia, Prymak Tetiana \\ National University of Food Technologies
}

\begin{abstract}
У нинішніх умовах нестабільної економіки, яка постраждала через пандемію COVID-19, конкурентні переваги і стратегії їх досягнення являють собою практичний інтерес для туристичних підприємств і виступають невід'ємним елементом фрормування загальної виробничої стратегії в цілому. У статті проаналізовано концепції як вітчизняних дослідників проблеми конкурентоспроможності підприємств, так і зарубіжних вчених. Перераховано фрактори, які мають вплив на фрормування конкурентних переваг підприємства. Розглянуто зміни у конкурентній ситуації в туристичній галузі, викликані сучасним станом внаслідок пандемії COVID-19. Особливу увагу приділено напрямкам досягнення конкурентних переваг, або діловим стратегіям, які можуть застосовуватися туристичними підприємствами. За результатами дослідження, автори приходять до висновку, що чітке фрормулювання, визначення, реалізація конкурентних переваг і вибір конкурентної стратегії, а також всебічний аналіз фракторів, що впливають на конкурентні переваги, забезпечить конкурентоспроможність підприємства на ринку туристичних послуг.

Ключові слова: конкуренція, конкурентна перевага, стратегії, конкурентоспроможність, конкурентна боротьба, туризм, туристичне підприємство.

В нынешних условиях нестабильной экономики, пострадавшей из-за пандемии COVID-19, конкурентные преимущества и стратегии их достижения представляют собой практический интерес для туристических предприятий и выступают неотъемлемым элементом формирования общей производственной стратегии в целом. В статье проанализированы концепции как отечественных исследователей проблемы конкурентоспособности предприятий, так и зарубежных ученых. Перечислено фракторы, которые влияют на фрормирование конкурентных преимуществ предприятия. Рассмотрены изменения в конкурентной ситуации в туристической отрасли, вызванные современным состоянием вследствие пандемии COVID-19. Особое внимание уделено направлениям достижения конкурентных преимуществ, или деловым стратегиям, которые могут применяться туристическими предприятиями. По результатам исследования, авторы приходят к выводу, что четкая фрормулировка, определение, реализация конкурентных преимуществ и выбор конкурентной стратегии, а также всесторонний анализ фракторов, влияющих на конкурентные преимущества, обеспечит конкурентоспособность предприятия на рынке туристических услуг.
\end{abstract}

Ключевые слова: конкуренция, конкурентное преимущество, стратегии, конкурентоспособность, конкурентная борьба, туризм, туристическое предприятие.

The article analyses the concept of competitive advantages, creating competitive advantages, model competitive advantages. The purpose of the article is to substantiate the theoretical aspects of the essence of the concepts of competition and competitive advantage, analysis of changes in the competitive situation in the market of the tourism industry and study of the crisis phenomena caused by COVID-19, to study the main approaches to the sources of competitive advantage, and their assessment taking into account external and internal factors. It is argued that competitive advantage is influenced by the factors such as infrastructure, the complexity of the business, labor and 
goods market efficiency, financial market complexity, innovation, technology, institutions of higher education and training, and macroeconomics. It is also believed that equally important for are both external as and internal factors. These factors determine whether a company is able to defeat its rivals and lead the market. Competition has its theoretical models and competitive advantage in the development of strategies as part of the targeted helps companies gain a competitive advantage over the competition. It is important to regularly monitor and examine the target competitors' strategies to quickly respond to their actions in order to grasp how to overcome them and find themselves in the leadership position it so that to survive and conquer the market. According to the study, the authors conclude that a clear formulation, definition, implementation of competitive advantages and choice of competitive strategy, as well as a comprehensive analysis of factors influencing competitive advantages, will ensure the competitiveness of the enterprise in the market of tourist services. In the current conditions of unstable economy, due to the COVID-19 pandemic, competitive advantages and strategies for achieving them constitute a practical interest for tourism enterprises and act as an integral part of the formation of public-production strategy in general. It is necessary to focus on the fact that the competitiveness of supply and available resources of the enterprise were sufficient to implement a certain strategy and obtain the desired results.

Keywords: competition, competitive advantage, strategies, competitiveness, competition, tourism, tourism enterprise.

Постановка проблеми. У вітчизняній економіці термін «конкурентна перевага» не використовувався до останнього десятиліття XX століття. Перехід до ринкової економіки і приватної власності послужив кроком до фрормування і зміцнення конкуренції у всіх сорерах діяльності. Зміни, які були викликані економічною та фрінансовою кризою, позначились на діяльності кожного підприємства. Результатом фрінансово-економічної кризи $€$ порушення виробничих, економічних і фрінансових відносин не тільки всередині самої компанії, але і у взаєминах зі споживачами і постачальниками. Така ситуація змушує керівників компанії займатися не стратегічними завданнями компанії, а вирішенням поточних проблем, що може вплинути на ефективність розвитку в майбутньому.

На сьогоднішній день багато підприємств не мають стратегічної концепції, що, в свою чергу, призводить до виснаження ресурсів, а також до загальної неконтрольованості всіх матеріальних і фрінансових потоків. У період зростання конкуренції підприємства повинні мати можливість швидко і адекватно реагувати на зміни ринкових умов. В результаті виникає реальна потреба в створенні та впровадженні механізмів управління, які дозволяють здійснювати ці зміни, визнавати їх і забезпечувати відповідну адаптацію економічної діяльності, заснованої на сучасних принципах маркетингу, менеджменту [6, с. 73].

Більш того, у зв'язку 3 швидким поширенням COVID-19 і введених урядом обмежень на поїздки по всьому світу, індустрія туризму знаходиться в самому центрі одного з найважчих періодів на сьогоднішній день. Туристичні бренди і маркетологи стикаються з дилемою, коли необхідно балансувати між заходами щодо здоров'я та створенням умов для подорожей, згідно переваг своїх споживачів. Це являє безпрецедентну проблему для галузі, та потребує розробки шляхів виходу з кризи, спричиненої пандемією COVID-19.

Приватні підприємці та власники підприємств почали задумуватися про конкурентоспроможність виробленої продукції (товарів та послуг). Нормальне фрункціонування підприємств передбачає пошук, а також розробку власної стратегії розвитку. Формування стійких конкурентних переваг є обов'язковою умовою для забезпечення ефективного розвитку підприємства.

Аналіз останніх досліджень і публікацій. Багато зарубіжних вчених, наприклад, такі як, Д.А. Аакер, І. Ансофрф, М. Портер, К. Боумен, Ж.Ж. Ламбен, Г. Мінцберг та ін. присвятили свої праці вивченню проблеми орормування конкурентних переваг фірми.

Значний внесок у дослідження проблеми конкурентоспроможності підприємств внесли і вітчизняні вчені, такі як: Г.Л. Азоєв, В.Д. Андріанов, О.Н. Беленов, Ю.Б. Рубін, В.М. Тумін, Р.А. Фатхутдінов.

Однак залишається ряд нерозглянутих питань, пов'язаних 3 нематеріальними фракторами конкуренції - репутацією, іміджем, партнерством, соціальною відповідальністю бізнесу, комунікаціями нового типу.

Метою статті $€$ обґрунтування теоретичних аспектів щодо сутності понять конкуренції та конкурентних переваг, аналіз змін у конкурентній ситуації на ринку індустрії туризму та вивченні кризових явищ, спричинених COVID19, вивчення основних підходів до джерел формування конкурентних переваг, та їхня оцінка з урахуванням фракторів зовнішнього і внутрішнього середовища.

Виклад основного матеріалу дослідження. Конкурентоспроможність товару це не тільки висока якість і технічний рівень, а й вміле маневрування в ринковому просторі 
і в часі, а головне, максимальне врахування вимог і можливостей конкретних груп покупців. Тільки на основі критеріїв, якими оперує споживач, для якого цей товар призначений, може бути проведена об'єктивна оцінка рівня конкурентоспроможності. Причини конкурентоспроможності товару слід шукати в конкурентних перевагах окремих його характеристик, які $€$ наслідком більш есрективного управління процесом розробки, реалізації та експлуатації пропонованої продукції [2, с. 125].

Різні напрямки менеджменту, маркетингу, права протягом досить тривалого часу вивчали механізм конкуренції, його рушійні сили. Конкуренція виступає в ролі стихійного регулятора суспільного виробництва. 3 одного боку, в результаті конкуренції загострюються виробничі і ринкові відносини, з іншого - підвищення ефрективності господарської діяльності. На сьогоднішній день не можна говорити про повністю сорормовану теорію конкуренції і моделі оцінки конкурентоспроможності сорери послуг, але багато аспектів мають закінчений вигляд і допомагають правильно орієнтувати прикладні розробки і практичні дії щодо посилення конкурентної позиції підприємства на ринку. Створення конкурентних переваг перед суперником стає стратегічним напрямком діяльності держави і державних органів в галузі забезпечення конкурентоспроможності національної економіки.

Так, конкурентні переваги підприємства це ті явища і процеси виробництва і господарської діяльності підприємства і соціально-економічного життя суспільства, які призводять до зміни рівня конкурентоспроможності підприємства [1, с. 554].

Зазвичай в умовах гострої конкурентної боротьби переможцем виходить той, хто зуміє досягти значних конкурентних переваг, причому не стільки над конкурентами, скільки по відношенню до споживача.

Конкурентна перевага, якою володіють на конкретних ринках різні суперники (конкуренти) - $€$ істотним фрактором клімату або конкурентної ситуації на ринку товару. Конкурентна перевага заснована на ряді специфічних характеристик, характеристик товарів або брендів, які створюють певну перевагу компанії над її основними конкурентами.

В ході свого дослідження, Ж.Ж. Ламбен встановив, що конкурентними перевагами служать ті характеристики продукту або бренду, які забезпечують компанії певну перевагу над його безпосередніми конкурентами [2, c. 165].
Р.А. Фатхутдінов розглядає конкурентну перевагу «як ексклюзивну цінність, якою володіє система і яка дає їй перевагу над конкурентами».

Іншими словами, конкурентні переваги це переваги компанії в порівнянні 3 конкурентами в сорері діяльності, в конкретній ситуації (на даному ринку або в сегменті, в певний час і т.д.) Або в виробництві товарів. Вони проявляються у ставленні споживача до підприємства. Перевага в тій чи іншій сфрері дозволяє надавати клієнтам ті блага, які мають для них підвищену цінність, що забезпечується більш низькою ціною, високою якістю і рівнем обслуговування. Це привабливо для клієнтів і гарантує більш високу, на відміну від конкурентів, рентабельність і конкурентоспроможність, а також відрізняє компанію від ії суперників.

Базуються конкурентні переваги на тому, що компанія володіє рідкісними матеріальними і нематеріальними активами, а також стратегічно важливими сорерами діяльності. Вони реалізуються на рівні стратегічних напрямків діяльності і складають головну мету ділової стратегії підприємства, що спрямована на завоювання ним міцної позиції на ринку. Однак рано чи пізно, незважаючи на всі зусилля, вони руйнуються в результаті старіння, імітації його товару або послуги іншими орірмами тощо. Перевага характеризується відносною, порівняльною позицією організації по відношенню до конкурента, що займає найкращу позицію на ринку товару або в сегменті ринку.

На зміну теорії порівняльних переваг, розробленої Д. Рікардо, прийшла теорія конкурентних переваг М. Портера. На думку Д. Рікардо, порівняльні переваги «обумовлені використанням країною (фрірмою) фракторів виробництва (трудових і сировинних ресурсів, капіталу та ін.), які $€$ в достатку. Але глобалізація і науково-технічний прогрес привели до того, що на базі достатку переваги не $€$ міцними, а увага, яка концентрується на них, гальмує науково-технічний прогрес і впровадження його досягнень. Внаслідок цього на зміну порівняльним приходять конкурентні переваги».

Як в масштабах однієї держави, так і в масштабі світової економіки, володарями властивостей конкурентних переваг $€$ різні суб'єкти конкурентоспроможності. Наприклад, види продукції, підприємства та організації або їх групи, що утворюють галузеві або конгломератні об'єднання, окремі країни або їх об'єднання (регіональні, політичні, етно- 
культурні), що ведуть конкурентну боротьбу за лідерство в різних сорерах міжнародних фрінансових взаємовідносин.

На думку М. Портера, неможливо виділити сильні і слабкі сторони діяльності підприємства, якщо розглядати підприємство в цілому, оскільки його конкурентні переваги фрормуються в ході багатобічної діяльності, а саме в процесі проектування, виробництва, маркетингу, а також при виконанні допоміжних фрункцій.

Діяльність підприємства в запропонованій М. Портером «ланцюжку цінностей» ділиться на дві частини:

- первинна діяльність (матеріально-технічне постачання, виробництво, маркетинг і збут);

- вторинна діяльність (розвиток технологій, управління персоналом, управлінська інфрраструктура).

Кожен 3 напрямків діяльності може сприяти зниженню витрат, створюючи основу для диференціації продуктів і послуг. Досліджуючи процес крок за кроком, можна розрахувати, де компанія конкурентоспроможна, а де вразлива.

Сьогодні фоормування конкурентних переваг підприємства, компанії зазвичай відбувається під впливом багатьох фракторів. Елементи виробничо-господарської системи (технологія, кадри, фрінансові кошти та інші) і елементи бізнес-системи (конкуренти і їх можливості, галузевий ринок та інші) виступають фрактором або ж умовою, яка визначає характеристики будь-якого об'єкта або процесу [4, с. 245].

Фактори, що впливають на формування конкурентної переваги срірми, можна розділити на дві групи: зовнішні і внутрішні [7, c. 122].

Зовнішні чинники, наприклад, такі як заходи державного впливу, характеристики ринку, діяльність громадських і недержавних органів, склад споживачів підприємства, партнери фрірми в малій мірі залежать від організації і характеризуються наявністю певного ступеня невідомості, проте їх можна використовувати в своїх цілях.

Внутрішні чинники, наприклад, внутрішньофрірмова культура, ресурси компанії, структура, визначаються керівництвом компанії, досягаються і реалізуються ії̈ персоналом.

Конкурентні переваги підприємства повинні відповідати наступним вимогам [8, с. 129]:

1. значимість - переваги повинні відрізнятися від конкурентів;
2. видимість - переваги повинні бути помітні покупцями;

3. значимість для споживача;

4. стійкість - переваги повинні зберігати свою значущість в умовах змін середовища;

5. унікальність - тобто підприємство повинно мати таку вигоду, якої немає у інших виробників товару;

6. прибутковість для компанії, що має сприяти успішному фрункціонуванню підприємства на ринку.

Конкурентні переваги повинні обов'язково знайти реальне втілення в продукті, його ціні, якості обслуговування, низьких витратах i інших показниках діяльності компанії, а також повинні сприйматися споживачем, тобто вимірюватися на основі економічних показників: більш висока рентабельність, більші частки ринку, більш високий рівень залучення споживачів та інші. Переваги, які не були реалізовані в конкурентній боротьбі, не є перевагами, оскільки не спричинили нові результати діяльності, не привели до позитивних змін стану підприємства.

Споживачі не залишають без уваги таку важливу характеристику компанії, як орормування та реалізація конкурентних переваг. Фірма, конкуруючи на ринку, намагається бути кращою, завойовуючи увагу споживача, застосовуючи при цьому всі конкурентні переваги, наявні в організації. Завдяки такій роботі, переможцем стає не та компанія, яка пропонує споживачеві більш дешевий, якісний товар, а та, яка зуміє задовольнити не тільки насущні потреби покупця, а й ті, які можуть у нього виникнути завтра: маркетинг сучасності орієнтований на так звані «потреби майбутнього» [3, с. 30].

Розглянемо зміни у конкурентній ситуації в туристичній галузі, викликані сучасним станом внаслідок пандемії COVID-19. Світовий спалах COVID-19 зупинив світ, і туризм постраждав найбільше 3 усіх основних секторів економіки - падіння в деякі місяці складало до 90\%.

Сценарії для сектору туризму вказують на те, що кількість міжнародних туристів може зменшитися на $58 \%$ до $78 \%$ у 2020 році, що призведе до падіння витрат туристів 3 1,5 трлн. доларів у 2019 році до між 310 та 570 млрд. дол. у 2020. Це ставить під загрозу понад 100 мільйонів прямих туристичних робочих місць, багато з яких на мікро-, малих та середніх підприємствах (ММСП), на яких зайнята висока частка жінок та молоді [10].

На рис. 1 показано кореляцію між кількістю підтверджених випадків COVID-19 та кіль- 


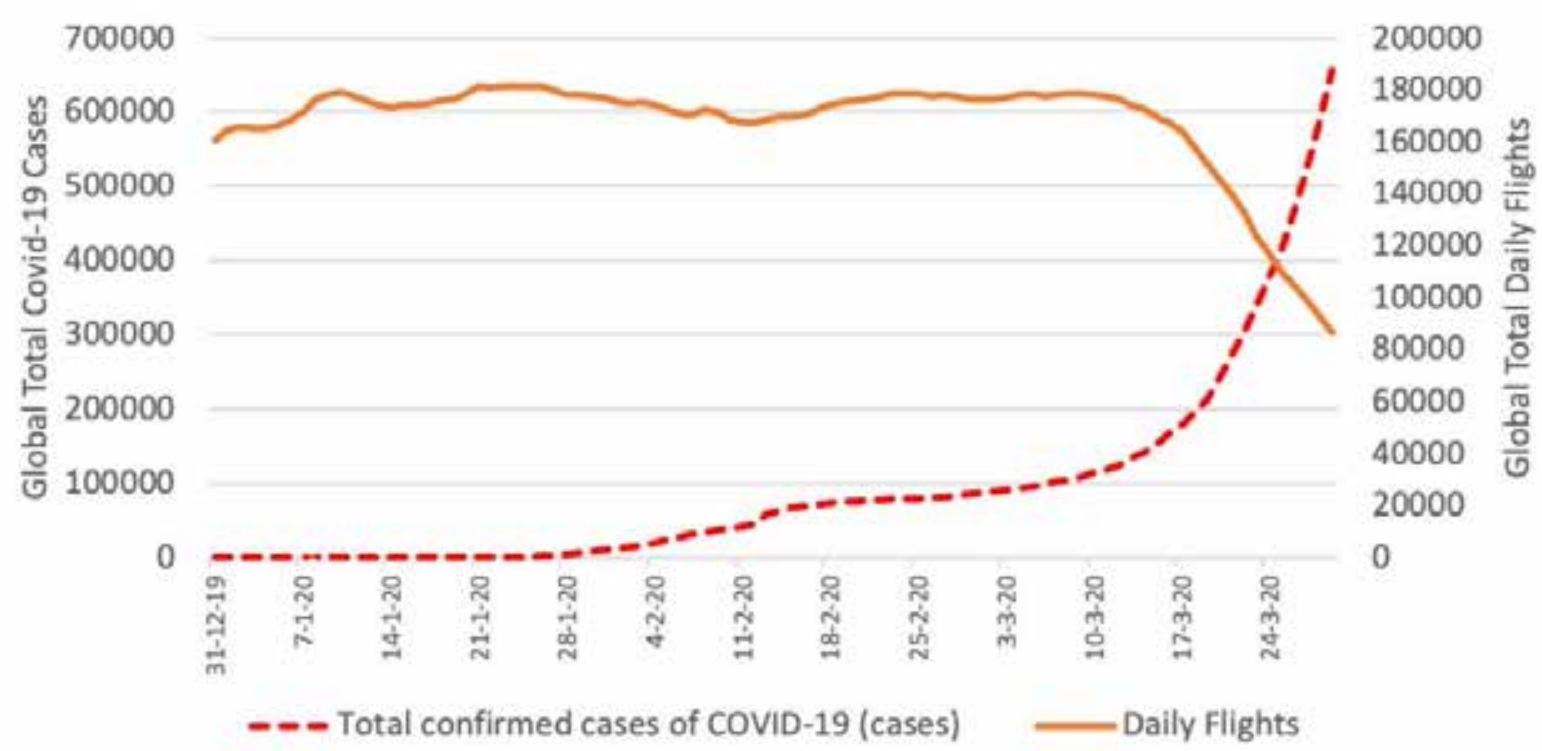

Рис. 1. Взаємозв'язок між кількістю підтверджених випадків COVID-19 та кількістю щоденних польотів в 1 кварталі 2020 року [9]

кістю щоденних польотів, яка яскраво демонструє критичний вплив пандемії на туристичну галузь [9].

Жодна країна не уникнула зменшення свого туристичного сектору - від Італії, де на туризм припадає 6 \% ВВП країни, до Палау, де вона генерує майже 90 \% всього експорту. Ця криза є серйозним потрясінням для розвинених економік та надзвичайною ситуацією для найбільш вразливих груп населення та країн, що розвиваються.

Драматичне падіння туристичних прибуттів в 2020 році, викликане наслідками пандемії COVID-19, призвело до радикальних змін на туристичному ринку, зміщення акцентів у взаємовідносинах між туроператорами, турагентами, онлайн-тревел агентами (ОТА), виробниками туристичних послуг тощо. Однак, під час кризи основні виклики для галузі не змінюються докорінно. Загальна мета залишається незмінною. Що відрізняється, так це те середовище, в якому можна досягти цієї мети.

Навіть у сприятливі економічні часи звички споживачів у подорожах змінюються, і витрати потрібно більш ретельно контролювати. Однак у кризові періоди клієнти взагалі стають ще більш вимогливими. Створення доданої вартості стає більш важливим для бізнесу з метою залучення клієнтів. Зростає важливість належного дослідження ринку. Оскільки деякі групи споживачів утримуються від поїздок, надмірна пропозиція на ринку призводить до посилення конкуренції, і клієнти отримують більш широкий вибір. Це означає, що особливо ті підпри- ємства, які не здатні забезпечити додану вартість, відчуватимуть труднощі.

Потреба вдосконалення підприємництва, інновацій та профресіоналізму, щоб мати можливість надавати високоякісні послуги, стає ще більш вираженою в цій економічній кризі, ніж в інші часи. Подібним чином співпраця через ланцюжок створення вартості стає критично важливою для залучення споживачів в умовах економічної рецесії.

Це означає, що планування дій щодо підвищення конкурентоспроможності також $€$ дуже актуальним під час кризи і часто навіть більш нагальним, оскільки проблеми стають все гострішими.

Збільшиться фрокус на персоналізації побажань туриста. Клієнти будуть шукати індивідуальні рішення, які відповідають їх власній індивідуальності. Суспільство вже не можна буде розділити на однорідні та впізнавані цільові групи, але воно ставатиме дедалі неодноріднішим із багатьма різними нішевими групами. Поведінку споживачів буде все важче передбачити. Один індивідуальний споживач може належати до одного сегмента одного дня, і до іншого сегмента наступного дня.

Зі збільшенням кількості подорожей поступово зростатиме попит на спеціалізовані послуги. Посилена увага до конкретних цільових груп та ніш буде ключем до успіху в майбутньому. Пакетні подорожі стануть меншими за кількістю учасників на групу, що дозволить більш гнучким маршрутам задовольнити різні потреби клієнтів у межах однієї групи. 
Туристи в майбутньому будуть намагатися відвідати більшу кількість різних дестинацій, що призведе до нижчої лояльності до одного чи кількох напрямків. Більше того, туристи демонструватимуть змішану поведінку у подорожах. Тому повторні відвідування зменшаться, а маркетинг дестинацій стане більш складним. Невпевненість у планах на фроні загальної економічної невпевненості призводить до того, що клієнти максимально вичікують з бронюванням аж до дати подорожі, і потребують набагато більше персональної уваги, консультацій і супроводу. Це повертає і підвищує актуальність турагентів на ринку, і навпаки, знижує вагомість OTA, як максимально де-персоналізованих та унісрікованих посередників на ринку.

Якщо ж говорити про стратегії управління потребами покупця, то вони можуть бути абсолютно різними. Наприклад, компанія може застосувати стратегію збільшення обсягу збуту існуючого товару на старому ринку за допомогою збільшення інтенсивності споживання за рахунок агресивної ринкової політики або ж вибрати стратегію, засновану на виробництві нового продукту і фрормуванні нового способу життя споживача, відповідного споживання цього продукту.

В економіці розроблено безліч напрямків досягнення конкурентних переваг, або ділових стратегій, але серед найбільш загальних виділяють:

- лідерство за витратами (собівартості продукції);

- диференціація продукції;

- фрокусування (концентрації);

- ранній вихід на ринок (стратегія першопрохідця);

- синергізм.

Стратегія лідерства за витратами полягає у використанні таких ресурсів, як ноу-хау, автоматизація, унікальний доступ до дешевих сировинних або трудових ресурсів, есрект масштабу і т.д., які в свою чергу допомагають компанії досягти істотної переваги над конкурентами за собівартістю свого товару [4, с. 177].

Компанії, які в своїй діяльності використовують стратегію диференціації, прагнуть бути унікальними за пропонованою групою товарів, відмінними від конкурентів в своїй галузі за тими характеристиками, які найбільше цінують покупці.

Стратегія диференціації $€$ ефективною в тому випадку, якщо споживач високо оцінює відмінні властивості і різноманітні способи використання товару, а сама диференціація продукту має безліч аспектів. Досягти цього можна за допомогою технічної переваги, якості надання послуг, підвищення цінності грошей (продаж в кредит) [5, с. 313].

На відміну від наведених вище стратегій, стратегія фокусування включає в себе досягнення переваг за витратами (фокусування на витратах) або дисреренціювання (фокусування на диференціюванні) у вузькому сегменті галузі. Іншими словами, компанія вибирає товар 3 високою споживчою цінністю, що відповідає ії очікуванням за основними споживчими властивостями, і перевищуючий їі очікування в ціні.

Цю стратегію доцільно використовувати в тих випадках, коли:

1. покупці цінують високу ступінь диференціації продукту, але чутливі до ціни;

2. фрірма має можливості виробництва продукції якості вище середнього при витратах вище, ніж у конкурентів.

Стратегії вважаються перспективними, якщо вони спрямовані на досягнення високої якості і унікальних характеристик продукції шляхом збільшення продуктивності, і мінімізації витрат.

Стратегію першопрохідника або ж перевагу першого ходу доцільно застосовувати в тому випадку, коли відбувається створення товару або послуги до появи конкурентів. Компаніяпершопрохідник $є$ привабливою для багатьох споживачів, так що для зміни поведінки значної частини ринку їі конкурентам доведеться докласти величезні зусилля.

Синергетичний ефект досягається шляхом використання ноу-хау, спільного використання ресурсів, створення переваги при узгодженості термінів окремих проектів, виграшу в якості, зростання довіри споживачів кінцевого результату.

Висновки. Таким чином, можна сказати, що чітке фрормулювання, визначення, реалізація конкурентних переваг і вибір конкурентної стратегії, а також всебічний аналіз факторів, що впливають на конкурентні переваги, забезпечують конкурентоспроможність підприємства на ринку туристичних послуг.

У нинішніх умовах нестабільної економіки, внаслідок пандемії COVID-19, конкурентні переваги та стратегії їх досягнення представляють собою практичний інтерес для туристичних підприємств та виступають невід'ємним елементом формування громадсько-виробничої стратегії в цілому. Необхідно орієнтуватися на те, щоб конкурентоспроможність пропозиції і наявні ресурси підприємства були достатні для реалізації певної стратегії і отримання бажаних результатів. 


\section{СПИСОК ВИКОРИСТАНИХ ДЖЕРЕЛ:}

1. Ваценко І.С. Формування конкурентних переваг сучасного підприємства. Молодий учений. 2015. № 10. C. 553-556.

2. Веснін В.Р. Стратегічний менеджмент : підручник. Москва : Проспект, 2017. 328 с.

3. Жиронкін С.А., Кадникова О.В. Безперервне соціальне благополуччя в XXI ст. Теорія і практика суспільного розвитку. 2016. № 3. С. 29-31.

4. Круглик В.М. Конкурентоспроможність підприємства (фрірми): навчальний посібник. Мінськ : Нове знання, 2015. $284 \mathrm{C}$.

5. Ламбен Ж.Ж. Менеджмент, орієнтований на ринок. Санкт-Петербург : Пітер, 2006. 866 с.

6. Плужникова Н.В. Напрями формування конкурентної переваги підприємства. Науково-методичний електронний журнал «Концепт». 2015. Т. 23. С. 71-75.

7. Портер М. Конкуренція: пер з англ. Москва : Видавничий дім «Вільямс», 2010. 206 с.

8. Стельмах Ю.В. Сучасний конкурентний аналіз і методи його проведення. Маркетингові комунікації. 2013. № 2. C. 120-132.

9. Pandemics, tourism and global change: a rapid assessment of COVID-19. URL: https://www.tandfonline.com/ doi/full/10.1080/09669582.2020.1758708 (дата звернення: 14.12.2020).

10. Policy Brief: COVID-19 and Transforming Tourism. URL: https://webunwto.s3.eu-west-1.amazonaws.com/ s3fs-public/2020-08/SG-Policy-Brief-on-COVID-and-Tourism.pdf (дата звернення: 14.12.2020).

\section{REFERENCES:}

1. Vatsenko I.S. (2015) "Formation of competitive advantages of the modern enterprise". Molodyj uchenyj, vol. 10, pp. 553-556.

2. Vesnin V.R. (2017) Stratehichnyj menedzhment [Strategic management]. Moscow: Prospekt.

3. Zhyronkin S.A., Kadnykova O.V. (2016) "Continuous social well-being in the XXI century". Teorija i praktika obshhestvennogo razvitija, vol. 3, pp. 29-31.

4. Kruhlyk V.M. (2015) Konkurentospromozhnist' pidpryiemstva (firmy) [Competitiveness of the enterprise (firm)]. Minsk: Nove znannia.

5. Lamben Zh.Zh. (2006) Menedzhment, oriientovanyj na rynok [Market-oriented management]. Saint-Petersburg: Piter.

6. Pluzhnykova N.V. (2015) "Directions of formation of competitive advantage of the enterprise". Kontsept, [Online]. Available at: https://e-koncept.ru/2015/95259.htm (accessed 14.12.2020).

7. Porter M. (2010) Konkurentsiia [Competition]. Moscow: Vil'iams.

8. Stel'makh Yu.V. (2013) "Modern competitive analysis and methods of its implementation". Grebennikov, vol. 2, pp. 120-132.

9. Pandemics, tourism and global change: a rapid assessment of COVID-19 (2020). Available at: https://www.tandfonline.com/doi/full/10.1080/09669582.2020.1758708 (accessed 14.12.2020).

10. Policy Brief: COVID-19 and Transforming Tourism (2020). Available at: https://webunwto.s3.eu-west-1.amazonaws.com/s3fs-public/2020-08/SG-Policy-Brief-on-COVID-and-Tourism.pdf (accessed 14.12.2020). 